\title{
Imatinib: the controversial discussion on cardiotoxicity induced by endoplasmic reticulum (ER) stress
}

\author{
R. Marchan $\cdot$ H. M. Bolt
}

Published online: 11 February 2012

(C) Springer-Verlag 2012

The safety profile of imatinib, and especially its relevance to cardiotoxicity, has been controversially discussed in recent years (Kerkelä et al. 2006; Herman et al. 2011; Wolf et al. 2010; Ribeiro et al. 2008). Therefore, the editors are pleased that Eirini Thanopoulou and Ian Judson from the Royal Marsden NHS foundation Trust in London contributed a comprehensive review on the long-term tolerability of imatinib (Gleevec) (Thanopoulou and Judson 2012).

The introduction of imatinib represents one of the most prominent success stories in cancer therapy of the past decade. A reciprocal translocation creating the Philadelphia chromosome is involved in pathogenesis of more than $90 \%$ of the cases of chronic myelogenous leukaemia (CML) (Van Etten 2004). This translocation creates the $\mathrm{Bcr}-\mathrm{Abl}$ fusion protein of the nonreceptor tyrosine kinase $\mathrm{c}-\mathrm{Abl}$ and the multidomain protein $\mathrm{Bcr}$, leading to a constitutively active cytosolic protein that activates several signalling pathways involved in proliferation and antiapoptosis. Imatinib inhibits the fusion protein, Bcr-Abl resulting in remission in a high fraction of patients with CML. In addition, imatinib is efficient in gastrointestinal stromal tumour (GIST), because-besides its effect on Bcr-Abl-it also inhibits KIT proteins that play a role in progression of GIST and other tumours (Joensuu et al. 2001; Micke et al. 2003, 2004). The success stories of imatinib, and the Her-2-targeting antibody, trastuzumab, led to the novel concept of identifying and targeting the mechanisms responsible of tumour progression, in addition to identifying subtypes of carcinomas with the perspective

R. Marchan $(\bowtie) \cdot$ H. M. Bolt

Leibniz Institut für Arbeitsforschung an der TU Dortmund, Leibniz Research Centre for Working Environment and Human Factors (IfADo), Ardeystrasse 67, 44139 Dortmund, Germany e-mail: marchan@ifado.de of a biologically justified therapy (Schmidt et al. 2008, 2010; Hellwig et al. 2010; Cadenas et al. 2010; Lee et al. 2010; Brase et al. 2010; Petry et al. 2010).

Previously, Kerkelä et al. (2006) reported on the cardiotoxic side effect of imatinib. Individuals without any prior history of heart disease developed heart failure after treatment with imatinib (Kerkelä et al. 2006). Interestingly, imatinib also showed toxic effects on cultivated cardiomyocytes, most likely due to an induction of endoplasmic reticulum (ER) stress, leading to decreased translation and a block in protein synthesis (Kerkelä et al. 2006). A simultaneous upregulation of stress response genes suggested that the ER stress response is an adequate mechanism to compensate short-term cell stress. However, prolonged activation may induce cell death by pathways, including Jun N-terminal kinases (JNKs), a mechanism shown for imatinib in cardiomyocytes (Kerkelä et al. 2006). Since cardiotoxicity is one of the leading topics in toxicology addressed in our journal (Sumi et al. 2011; Vávrová et al. 2011; Lee et al. 2010), we welcome the current review by Thanopoulou and Judson (2012). Overall, imatinib shows an excellent long-term tolerability and the clinical relevance of imatinib-induced cardiotoxicity may have been overestimated. The comprehensive review of Thanopoulou and Judson (2012) comes highly recommended for anyone interested in the safety profile of imatinib.

\section{References}

Brase JC, Schmidt M, Fischbach T, Sültmann H, Bojar H, Koelbl H, Hellwig B, Rahnenführer J, Hengstler JG, Gehrmann MC (2010) ERBB2 and TOP2A in breast cancer: a comprehensive analysis of gene amplification, RNA levels, and protein expression and their influence on prognosis and prediction. Clin Cancer Res 16(8):2391-2401 
Cadenas C, Franckenstein D, Schmidt M, Gehrmann M, Hermes M, Geppert B, Schormann W, Maccoux LJ, Schug M, Schumann A, Wilhelm C, Freis E, Ickstadt K, Rahnenführer J, Baumbach JI, Sickmann A, Hengstler JG (2010) Role of thioredoxin reductase 1 and thioredoxin interacting protein in prognosis of breast cancer. Breast Cancer Res 12(3):R44

Hellwig B, Hengstler JG, Schmidt M, Gehrmann MC, Schormann W, Rahnenführer J (2010) Comparison of scores for bimodality of gene expression distributions and genome-wide evaluation of the prognostic relevance of high-scoring genes. BMC Bioinf 25(11): 276

Herman EH, Knapton A, Rosen E, Thompson K, Rosenzweig B, Estis J, Agee S, Lu QA, Todd JA, Lipshultz S, Hasinoff B, Zhang J (2011) A multifaceted evaluation of imatinib-induced cardiotoxicity in the rat. Toxicol Pathol 39(7):1091-1106

Joensuu H, Roberts PJ, Sarlomo-Rikala M et al (2001) Effect of the tyrosine kinase inhibitor STI571 in a patient with a metastatic gastrointestinal stromal tumor. N Engl J Med 344(14):10521056

Kerkelä R, Grazette L, Yacobi R, Iliescu C, Patten R, Beahm C, Walters B, Shevtsov S, Pesant S, Clubb FJ, Rosenzweig A, Salomon RN, Van Etten RA, Alroy J, Durand JB, Force T (2006) Cardiotoxicity of the cancer therapeutic agent imatinib mesylate. Nat Med 12(8):908-916

Lee JH, Jung C, Javadian-Elyaderani P, Schweyer S, Schütte D, Shoukier M, Karimi-Busheri F, Weinfeld M, Rasouli-Nia A, Hengstler JG, Mantilla A, Soleimanpour-Lichaei HR, Engel W, Robson CN, Nayernia K (2010) Pathways of proliferation and antiapoptosis driven in breast cancer stem cells by stem cell protein piwil2. Cancer Res 70(11):4569-4579

Micke P, Basrai M, Faldum A, Bittinger F, Rönnstrand L, Blaukat A, Beeh KM, Oesch F, Fischer B, Buhl R, Hengstler JG (2003) Characterization of c-kit expression in small cell lung cancer: prognostic and therapeutic implications. Clin Cancer Res 9(1):188-194

Micke P, Hengstler JG, Albrecht H, Faldum A, Bittinger F, Becker K, Wiewrodt R, Fischer B, Buhl R (2004) Characterization of c-kit expression in adenocarcinomas of the lung. Tumour Biol 25(5-6):235-242
Petry IB, Fieber E, Schmidt M, Gehrmann M, Gebhard S, Hermes M, Schormann W, Selinski S, Freis E, Schwender H, Brulport M, Ickstadt K, Rahnenführer J, Maccoux L, West J, Kölbl H, Schuler M, Hengstler JG (2010) ERBB2 induces an antiapoptotic expression pattern of Bcl-2 family members in node-negative breast cancer. Clin Cancer Res 16(2):451-460

Ribeiro AL, Marcolino MS, Bittencourt HN, Barbosa MM, Nunes Mdo C, Xavier VF, Clementino NC (2008) An evaluation of the cardiotoxicity of imatinib mesylate. Leuk Res 32(12):1809-1814

Schmidt M, Böhm D, von Törne C, Steiner E, Puhl A, Pilch H, Lehr HA, Hengstler JG, Kölbl H, Gehrmann M (2008) The humoral immune system has a key prognostic impact in node-negative breast cancer. Cancer Res 68(13):5405-5413

Schmidt M, Petry IB, Böhm D, Lebrecht A, von Törne C, Gebhard S, Gerhold-Ay A, Cotarelo C, Battista M, Schormann W, Freis E, Selinski S, Ickstadt K, Rahnenführer J, Sebastian M, Schuler M, Koelbl H, Gehrmann M, Hengstler JG (2010) Ep-CAM RNA expression predicts metastasis-free survival in three cohorts of untreated node-negative breast cancer. Breast Cancer Res Treat 125(3):637-646

Sumi D, Sasaki T, Miyataka H, Himeno S (2011) Rat H9c2 cardiac myocytes are sensitive to arsenite due to a modest activation of transcription factor Nrf2. Arch Toxicol 85(12):1509-1516

Thanopoulou E, Judson I (2012) The safety profile of imatinib in CML and GIST: long-term considerations. Arch Toxicol 86:1-12

Van Etten RA (2004) Mechanisms of transformation by the BCR$\mathrm{ABL}$ oncogene: new perspectives in the post-imatinib era. Leuk Res 28:21-28

Vávrová A, Popelová O, Stěrba M, Jirkovský E, Hašková P, Mertlíková-Kaiserová H, Geršl V, Simůnek T (2011) In vivo and in vitro assessment of the role of glutathione antioxidant system in anthracycline-induced cardiotoxicity. Arch Toxicol 85(5):525-535

Wolf A, Couttet P, Dong M, Grenet O, Heron M, Junker U, Laengle U, Ledieu D, Marrer E, Nussher A, Persohn E, Pognan F, Rivière GJ, Roth DR, Trendelenburg C, Tsao J, Roman D (2010) Imatinib does not induce cardiotoxicity at clinically relevant concentrations in preclinical studies. Leuk Res 34(9):1180-1188 